\title{
A Model of Task-Based Blended Learning for the EFL Writing Classroom
}

\author{
Anak Agung Raka Sitawati \\ Administration Department, Bali State Polytechnic, Kampus Bukit Jimbaran Street, Kuta Selatan, Badung-80364, Bali, \\ Indonesia \\ I Made Ardana Putra \\ Administration Department, Bali State Polytechnic, Kampus Bukit Jimbaran Street, Kuta Selatan, Badung-80364, Bali, \\ Indonesia \\ Ni Ketut Sucani \\ Administration Department, Bali State Polytechnic, Kampus Bukit Jimbaran Street, Kuta Selatan, Badung-80364, Bali, \\ Indonesia \\ I Made Rai Jaya Widanta \\ Mechanical Engineering Department, Bali State Polytechnic, Kampus Bukit Jimbaran Street, Kuta Selatan, Badung- \\ 80364, Bali, Indonesia \\ I Wayan Dana Ardika \\ Civil Engineering Department, Bali State Polytechnic, Kampus Bukit Jimbaran Street, Kuta Selatan, Badung-80364, \\ Bali, Indonesia \\ Putu Dyah Hudiananingsih \\ Accounting Department, Bali State Polytechnic, Kampus Bukit Jimbaran Street, Kuta Selatan, Badung-80364, Bali,
} Indonesia

\begin{abstract}
Online learning is being implemented due to the emergence of the COVID-19 pandemic. This is based on the reduction of cases and casualties to the danger and severity of the disease. Though several compliments were encountered in the implementation of this educational process, English instructors at secondary and tertiary levels continue to protest the change. To respond to this dilemma, the development of blended learning (a combination of online and offline learning) emerged. Therefore, this study was intended to develop task-based blended learning for English correspondence education and to identify and explain the learning aspects in the model development. Approximately 120 students from four classes of semester 6 were selected and divided into two groups (experiment and control groups) since a research and development model was used for analysis (Dick \& Carey, 1990). The draft model was further validated and piloted for several meetings. The results show effective learning materials containing five sections, namely (1) activity lead, (2) mind mapping, (3) refocusing, (4) writing, and (5) reinforcement. The materials were designed through the provision of tasks in every section, therefore integrating the students' use of four language skills. In addition, these materials were designed according to lesson plan, learning syntax, and assessment tools.
\end{abstract}

Index Terms - task based, blended learning, EFL, writing classroom, English for business correspondence

\section{INTRODUCTION}

Technology is presently being used to support English language learning worldwide due to the impact of the COVID19 pandemic on the education sector. Besides the introduction of this concept, technology implementation is intended to produce a more suitable method for learners. It is also empowered to ensure effective, efficient, and meaningful learning processes. Another aim of this technological concept is to provide assistance to every English teacher or lecturer, scholar, and expert. The most popular method for assisting language learning is information and communication technology. Additionally, several applications have been developed to facilitate language learning with model choices. This indicates that each application has specific features for the needs and fashion of learners.

The frequent and massive implementation of online learning has presently led to a new era in the education sector, with several institutions deciding to use a digital or blended model to support academic needs. Moreover, blended learning (online and offline learning) is presently popular among lecturers because the educational process promotes the easy use of several applications for distance and direct classes. Besides the specific percentage between distance and direct learning, lecturers still create time to meet their students to solve problems, directly convey materials, and advise 
students on projects and other works. For the learners, this learning model provides opportunities to interact with lecturers, which is very important for most students. In addition, teachers are enthusiastic in undertaking the learning model.

Due to the COVID-19 pandemic, all learning activities were conducted through an online model because all institutions globally switched to the total use of digital learning to avoid dangerous social interaction. Although the implementation of this model was difficult due to the emergence of several weaknesses, it was still advised to be conducted. This led to encounters with many educational obstacles such as inadequate materials, unavailable internet connections, knowledge restrictions on applications, learners' undisciplined attitudes, time limitations to access several sites, and a lack of direct social interaction.

However, blended learning has been redesigned to meet the needs of English learning, especially for international business correspondence in the Administration Department of Politeknik Negeri Bali, Indonesia. This is based on responding to the learners' needs and considering the problems, hindrances, and obstacles encountered during previous online and traditional learning. The redesigned learning model fundamentally uses task-based language teaching (TBLT) combined with blended techniques to support pedagogical activities. In addition, TBLT was selected due to being effectively implemented in several pedagogical interventions within Politeknik Negeri Bali, such as in Tourism and Administration Department classes (Somawati, 2017; Somawati, 2018; Sitawati, 2019). These successes enhanced the utilization of TBLT to redesign writing subject through the blended learning model.

\section{LITERATURE REVIEW}

\section{A. Some Critiques of Task-based Language Teaching}

Despite having received negative feedback, TBLT is an approach that has also received positive reviews depending on its implementation purposes. Based on learning forms or English language grammar, this approach was instructionally rejected by Japanese students due to obtaining good test results (Sato, 2009). Since the aims of this technique were students comprehending and producing sentences as well as using patterns and other grammar items, traditional models were found effective, including the grammar translation method; presentation, practice, production (PPP); and test, teach, test. This is in line with Bruton (2002), Sheen (1994), and Swain (2005), who claim that TBLT was very doubtful for the performance of Japanese learners for several reasons: (1) TBLT did not meet the Japanese students' needs due to their disinterest in communication skills, (2) TBLT is not in line with the pattern of Japanese learning, (3) TBLT decreased learners' motivation to succeed on tests, (4) TBLT is opposed to Confucian culture based on the belief that lecturers often had greater authority than students, (5) TBLT does not include a learning model focusing on forms or grammar, (6) TBLT breaks the principles of form-focused instruction, and (7) TBLT is assumed to cause language fossilization rather than acquisition among learners (Sheen, 1994; Hu, 2005; Swain, 2005; Burrows, 2008; Sato, 2009).

Widdowson (2003) has observed the weakness of TBLT based on its negligence regarding semantic meaning. This indicates that TBLT is indistinguishable from traditional learning activities. Furthermore, Sheedhouse (1999) asserts that TBLT merely proposes introductory tasks using impoverished language samples, leading to minimal improvement and acquisition, as well as pidginized linguistics. Additionally, it provides unpredictable language goals and outlaws grammar aspects in its syllabus (Swan, 2005) because grammar is not a salient aspect. Meanwhile, several experts disagree about and advocate for the reliability of TBLT. This approach was observed to be a failure in defending its purposive goal of facilitating learners' maximum language acquisition.

\section{B. Benefits of Task-based Language Teaching}

Based on the success of TBLT, a supportive belief was determined through the investigation of several studies, such as those by Ellis (2003), Skehan (1998), and Willis (2009). These researchers claim that the PPP approach failed to improve learners' communicative competence. Conversely, they indicate that TBLT suits the second language acquisition process due to having several strong points. Therefore, the benefits of this model include (1) reliability on communicative language teaching; (2) implementation failure reaction of PPP and test, teach, test; (3) treatment of the target language as a communication medium rather than a learning object; and (4) involvement of students in the utilization of language with meaningful presentations and practices. This is unlike PPP, which required students to learn forms. Moreover, Samuda and Bygate (2008), Mackey (1991), Little and Fieldson (2009), and Takimoto (2009) have also observed the effectiveness of TBLT. Samuda and Bygate (2008) stated that the task was an activity holistically involving learners achieving a nonlinguistic goal. This was due to providing learners with language utilization activities. Samuda and Bygate also advocated that TBLT was effective for several reasons: (1) provision of realistic language to learners, (2) an alternative approach to the problem encountered by Japanese learners, (3) provisions of input and real output, (4) the utilization of an input-based task helped in improving communicative competence, (5) provision of meaningful language use to learners, and (6) situation and condition adaptability (Mackey, 1991; Little \& Fieldson, 2009; Takimoto, 2009; Samuda \& Bygate, 2008).

Other studies also strengthened the effectiveness of TBLT in terms of integrativeness, indicating focus approach and grammar construction (Seyyedi \& Ismail, 2012; Rahimpour, 2008; Schmidt, 1990; Prabhu, 1987). The model was further found effective based on being integrated in a meaningful communication activity, indicating the aims of solving 
problems, completing projects, and making decisions (Seyyedi \& Ismail, 2012). For optimal performances, TBLT should be supported with an analytic syllabus about learners' ability to complete tasks in the target language culture (Rahimpour, 2008). Rahimpour (2008) claimed that apart from knowing the form or the language learners should also be aware of and competent at the culture under which the language exists. This situation will certainly make the learner to be pragmatically competent, that is they are able to use the language appropriately and effectively (Widanta, el at., 2018). In addition, a procedural syllabus on meaning and grammar construction approach should be in line with this model based on the learning process unconscious to the learners (Prahbu, 1987). Schmidt (1990) proposes that TBLT should enable learners to notice the input, such as syntactical, vocabulary, and phonological aspects. This indicates the ease for learners to acquire the language. To realize achievement in the learning process, learners should be grouped according to their abilities for two reasons: (i) to assist accelerated acquisition of more proficient students and (ii) to provide circular support for struggling students. In line with this, success of learners' language acquisition also depends on how inputs were given by teachers. Widanta, et al. (2020) claimed that inputs benefited learners when they were explicit and comprehensible by means of problem clarification, explicit concept building, and learners' awareness building.

\section{Task-based Language Teaching and Blended Learning}

The development of technology recently created a new atmosphere within the world of ESL or ELF because teachers were found to have switched to online and/or blended learning due to certain effectiveness. Online learning involves technology and is often known as e-learning (Ginaya, 2021). Ghazizadeh and Fatemipour (2017) state that blended learning was effective for Iranian students in terms of improving reading skills. This was because the model triggered students to extensively read through application texts. As young learners, they were enthusiastic, motivated, and confident to study reading exercises using gadgets. Furthermore, Adas and Bakir (2013) used blended learning to improve Palestinian learners' writing competence. This study investigated and eventually showed that the model was effective in specifically improving learners' writing skills and other supporting competences, including grammar, spelling, punctuation, and paragraph coherence. The results indicate that blended learning was able to channel learners' competences towards the achievement of good writing goals. In addition, the model assisted in speaking and listening classes as well as all language skills utilizing computer applications, blogs, and Facebook. Besides this success, several unclaimed studies indicated the challenges of blended learning. Therefore, the learners' perception of the implementation of the model demonstrated general agreements and satisfaction. This is likely to be the reason students are very confident and motivated towards the utilization of blended learning. However, the model was found to fail in the enrichment of vocabularies. Tosun (2015) showed that this model failed to improve learners' vocabulary knowledge. Blended learning also failed to provide a positive effect in the educational sector.

Other studies were also conducted in an attempt to implement only online learning through various aims. Pappas (2018) showed that blended learning provided learners with numerous resources through the availability of internet accessibility. Several scholars discovered the effect of this model on learners' self-motivation and educational activity through the utilization of authentic materials. Akbarov and Aydogan (2018) showed that blended learning motivated EFL learners through professional performances towards the achievement of academic goals. In line with this, Oweis (2018) states that blended learning positively impacted learners' achievement and motivation in understanding English. This indicates that the model affected learning performances and motivated students to authentically practice the language. According to Ju and Mei (2018), blended learning provides life-long knowledge and further encouraged learners to internally and externally practice the English language. It also showed that the model gave students the chance to effectively use their brains with information and communication technology spaces to practice the language more authentically. Zhan and Zhu (2018) and Rahim (2019) also discovered the encouraging effect of blended learning and state that the model substantially assisted learners in flexible, interactive, and highly educational environments. It was also found to be effective in meeting the characters of learners based on the reduction of anxiety levels. Similar to the learning trend of individual and collaborative learning, this model was found to be a possible solution. Moreover, blended learning was able to facilitate student-based education and collaborative tasks and assist teachers in designing a more efficient model. Therefore, technological integration ensured that the teaching-learning model coincided with the new paradigm in education, which caused the restructuring of future educational backgrounds.

Despite TBLT rarely being implemented in blended learning, one of the total related literatures still used it, especially speaking task (Rahim, 2019). Besides direct speaking performances, the study still utilized a video-recorded task, the narration of which was found to be very effective in increasing learners' creative ideas, learning time flexibility, and academic goal endorsement. These results were an inspiration for the execution of the present study, which did not use a video-recording task. The tasks used in this study were inserted or submitted into the Schoology application.

The aforementioned study on the implementation of blended learning for EFL or ESL classes was conducted using a common or conventional model. However, the teaching method used was not clearly mentioned and identified. In addition, several studies on writing only investigated the teaching method for general English skills. Furthermore, TBLT was not completely implemented in these studies because they mostly focused on teaching writing with blended or online learning and not on investigating a specific collaborative model. Therefore, the present study aims to combine blended learning with TBLT. Several questions specifically stated in this study are as follows: 
1) What is the aim of the designed TBLT-blended learning model?

2) What aspects were developed to ensure the functions of the model?

3) What challenges and benefits did the students encounter and obtain?

\section{METHOD}

\section{A. Participants}

This study involved four classes of 60 semester Administration Department students who were taught English for international correspondence for one session. These learners were further divided into two groups (i.e., two classes each for group A and B). Furthermore, groups A and B were classified as experiment and control categories, respectively. Due to having similar English competences, the students were grouped and registered as valid research participants. These selection criteria were stated by their English lecturer and further confirmed through the students' daily performances and formative test results.

\section{B. Data, Instrument, and Collection}

The data utilized in this study were the results of the TBLT-blended learning model, including the educational materials, teaching-learning syntax, assessment tools, TBLT online method, and students' and instructors' perceptions. The instruments used to collect the data varied and included a checklist, questionnaire, and assessment rubric. The checklist was used to value educational activities since teachers and students were assessed to determine the tendencies, strengths, and weaknesses of the proposed model. The questionnaire was also used to assist the focused group evaluation activities as well as the instructor's in-depth interviews with several participants. In addition, the assessment rubric was used to help validators score the model components.

\section{Procedure}

The procedure contained three stages, namely the preresearch, research, and postresearch activities. The preresearch stage was the initiation of all the activities, including locus preparation, participants, and coordinating with the instructor as well as the head of the department. The research stage further involved the main activities, such as development, preparation, validation, observation, and implementation. Meanwhile, the postresearch stage involved the completion of the processes through evaluation and tracing. Moreover, the model development was the most important stage in this study based on the integration of related activities. This was accompanied by the validation and implementation of the developed tools. To measure and ensure the effectiveness of the model, the process of evaluation was also necessary based on the users' and stakeholders' perceptions.

\section{Data Analysis and Result Presentation}

The data in this study were qualitatively analyzed, including model development, TBLT online learning combination, and the perception of the instructor's and students' perception of the proposed method. The results were also formally presented in the form of narration.

\section{RESULTS AND DisCUSSION}

\section{A. The Developed Model}

The development of the TBLT-blended learning combination was in line with the procedure proposed by Dick and Carey (1990), which basically included three factors: developing learning materials, assessments, and educational syntaxes.

\section{Developing Materials}

The learning materials were obtained from the former conventional resources adapted and adjusted with TBLT principles. These resources contained 12 units: basic principles, structure, business letter style (letter of enquiry and reply), quotation, placing and handling orders, account statement, requested and delayed payments, memorandum of complaint, international banking, application letter and CV, social business report, and e-mail and memoranda. The materials were abundant because students were obliged to study and finish all units in one semester, which consisted of four months with insufficient learning hours. In addition, some units contained repetition and review of former materials, which was time consuming. Therefore, an effort was made to minimize materials and combine units (similar topics, language functions, and learning target). For example, unit 1 concerning 'basic principles, structure, and style' was executed through the combination of schemes 1, 2, and 3 from the former conventional study. This process was conducted for students to complete the materials based on the consideration of learning hours and TBLT activities.

The learning objectives of each group were initially developed after mapping the module units. These objectives were rooted in the thematic and language goals of each unit. They also contained obtainable achievements for students after the completion of their learning activities. In addition, linguistic goals contained tense, structure or expression, grammar, and other formulas. Furthermore, the task materials of each unit were developed according to the proposed learning outcome, with several variations observed due to different target goals. These task types contained several activities, such as filling in gaps, matching, writing text, listening and noting information, identifying, stating 'yes' or 
'no' data, interview and written responses, completing and constructing sentences, comparing, mapping, role-playing, mentioning, and reading and answering. These types were arranged from the simplest to the most complicated.

Unit materials were developed to enhance students' production of writing, although other language skills such as speaking as well as reading and listening were also practiced. This was adequately empowered because students mostly acquired language through speaking or writing. For example, unit 1 contained several items such as nature knowledge and characteristics of business letters, principle explanation and letter organization, structure identification, memoranda placing parts, and formal report writing. Several tasks were also developed for students to comprehend and perform the required unit. Besides written structures, students should also possess the abilities to comprehend, interact with, and produce verbal expressions and perform other meaningful and realistic activities (Long, 1985; Breen, 1987; Nunan, 1989; Willis, 1996; Skehan, 1989; Ellis, 2003). To realize the target of the unit, these activities were operationally designed in some tasks, such as 'matching terms with meaning', 'asking more extended information using $5 \mathrm{Wh}$ and $1 \mathrm{H}$ questions', 'mapping ideas', 'interview through clues', and 'filling in forms'. These activities ensured that tasks should utilize natural language, promote verbal language use (Swan, 2005), provide natural learning pattern opportunities, focus on meaning, produce fertile inputs, prioritize fluency before accuracy (Ellis, 2009), engage learners in highcreativity activities, and use resources beyond the conventional standard (Hatip, 2005).

The materials used to support English business correspondence learning were deemed appropriate through two processes, namely validation by expert judges and instructor-learners' input. The validation by expert judges was conducted based on the development of materials. This was initially conducted before usage in the instructional activity. The goal of this process was to ensure the validation of materials in readiness for implementation in pedagogical intervention. Passing expert judgment ensured the reliability of the materials in supporting instructions, although they were not the only factor determining successful learning. Meanwhile, input from learners and instructors was necessary due to being responsible for the utilization of materials. This indicated that instructors and learners completely understood the performances of the materials to support learning. They also had knowledge of the material parts requiring revision for improvement. In addition, expert judges should have opinions and suggestions regarding revision of the materials.

The materials for each unit contained three or four tasks since one session was conducted in two hours. Each session began with topic introduction, speaking and main activities, and writing exercises. Writing was arranged for learners to create text or letters as outlined in the learning objective. Home assignments were also provided for more creative writing activity. Before its implementation, expert judges validated learning materials or modules.

\section{Developing Teaching and Learning Syntax}

Instructor and learners were one of the key points in the process of learning to create comprehensive and effective pedagogical activities. Besides the learning materials, these educational personnel also determined the performances of instruction. Therefore, any aspect related to instructors and learners should be appropriate, supportive, and reliable for the learning process. For the achievement of goals, teaching-learning syntax was found to be important. The provision of a lesson plan was also extremely essential in a learning process executed in an orderly manner. This was because random steps of instruction infrequently led to effective and focused activities, ensuring learners' consciousness of learning objectives. Therefore, learning syntax is important to instructors' and learners' goals based on the provision of educational ideas.

The syntax of TBLT-blended learning was designed to avoid wrong educational directions towards the achievement of goals. There were three main stages in this process, namely preteaching, teaching, and postteaching. Furthermore, the learning syntax was flexible depending on the needs of the educational process. This process is likely to be used for different durational sessions depending on the requirements of the learning process. Preteaching focuses on the introductory aspect of the lesson for learners to understand the contents of the materials. The models of the lesson should also be understood based on the combination of TBLT and blended learning in this study. In addition, the instructor should also state the type of lesson plan used due to several variations such as conventional, traditional, offline, or online TBLT. Besides explaining the learning objectives and durations required, the instructor used the syntax to explain the lesson expectations when conducted with an online model. Thus, learners were introduced to the methods of opening applications, accounts, and access codes to join the course. In this case, the introduction of the blended learning application was time consuming because several students were not familiar with the process compared to the conventional model.

The teaching stage was the main phase of this process due to its dominance in the learning activities. It contained more than one activity or task, especially when the learning hour was longer than 90 min. This process started with the conventional, direct, or digital distribution of tasks. In this case, Schoology was used to explain task execution, introduce linguistic features, model dialogues, and provide feedback. When the model used was blended or digital, modelling was conducted using videos and sent through the application. Learners were often provided with other tasks due to unfinished materials after previous activities. These normally involved extended speaking tasks, which enabled the practice of producing utterances in a verbal interaction. Moreover, the tasks were often based on interview, information, role play, et cetera. They also required learners to individually or collaboratively demonstrate performances. In addition, the purpose of oral or spoken tasks was to trigger learners' attention, awareness, and knowledge of the topic or language. This was because explicit experience in the form of production mostly stimulated 
learners to demonstrate strong knowledge and comprehension, leading to language acquisition (Schmidt, 1990; Widanta, 2017). The performance of spoken tasks frequently assisted students in improving their pragmatic competence due to their engagement with pragmatic interpretation during oral practices (Arnawa et al., 2021).

Based on the learning target being able to produce text, the conventional and digital activities often led to writing tasks, which were focused on the main topic of each unit. This included the learners' abilities to design business, enquiry, and cover letters while also arranging them in an orderly fashion. The last activity in the teaching phase was the provision of feedback on learners' work. This was provided in almost all activities and was very essential in evaluating work quality, weakness, and progress. The last stage of the three main stages of learning syntax was the postteaching stage, which involved general feedback, reinforcement, and home assignments. Before being utilized as a standard tool, the learning syntax had to pass validation by expert judges.

\section{Developing the Assessment Tool}

The last main tool designed in developing a learning model is assessment, which helps to measure the learners' achievement during educational activities. The tool contains two subaspects, namely the test and the rubric.

The test was conducted through the role-play model, which involves the evaluation of learners based on productive skill performances in writing letters. Therefore, the role-play method is the learning outcome of each unit. However, only several topics of total units were selected in the role-play cards, which required learners to write through the consideration of five aspects, namely format, content, grammar and spelling, language appropriateness, and concision. Based on format, learners should be able to write letters with good and standard precision. In addition, standard format comprehension helped learners ease a certain level of anxiety due to the satisfaction obtained from their performances. Besides format, the messages included within the body of a letter were also a strong and reliable point. Additionally, the directions for messages were included in role-play narration. Therefore, learners' comprehension of role-play was essential to succeed in writing an appropriate letter. The other three aspects of a good letter-grammar and spelling, language appropriateness, and concision-were implicitly expressed in the role-play. In addition, five aspects were also used to construct a parameter for measuring and scoring learners' output (i.e., the descriptor). This was adopted from the rubrics proposed and published on the internet.

The descriptor is the sign or parameter for scoring learners' writing skills. In this case, five segments were used to provide descriptions, namely format, content, grammar and spelling, language appropriateness, and concision. Each parameter could be rated 1 (needs improvement), 2 (satisfactory), 3 (very good), or 4 (excellent). Format concerned the items contained in a business letter, such as address, date, inside referral, attention line, salutation, content, closing, and signature. This aspect was very important because its comprehension led to awareness or consciousness in learners, which in turn increased their self-confidence and motivation to finish the letter. Learners are often confused when beginning to write a letter because they are unfamiliar with the format of a letter. The body or content of a letter is often used as a determinant because it is considered a goal factor during assessment. Therefore, the content of opening and closing paragraphs as well as messages was utilized as a parameter. When a learner fails to construct messages, the content conveyed in the letter certainly becomes difficult for readers to comprehend. Two linguistic properties that further emerged as parameters were grammar and spelling as well as language appropriateness. A comprehensible letter should contain grammatical sentences and correct spellings as well as appropriately selected words. When used in business domains, several words were found not to provide exact, familiar, and appropriate meanings. The final aspect to be considered in constructing a good letter is concision. A long-winded letter containing redundant and/or superfluous information is likely to lead to confusion among readers. Therefore, writers should be skilled in designing conscious letters to meet standard goals. Similar to other instruments, test and rubric assessment tools were validated by expert judges before use.

\section{B. Combining Task-based Language Teaching with the Blended Learning Model}

The blended learning model is a combination of digital/online and conventional/offline models due to the frequency set for both types of learning. Online learning helps socialize learners with technology and unit materials and provide opportunities for instructors and learners to virtually conduct educational activities during the COVID-19 pandemic era. The application used provided the resources of learning materials, such as videos, songs, articles, and news. In addition, learners expressed their ideas through various activities, such as recorded monolog, dialog, and drama. Besides TBLT, the online model also promotes learners through several methods, such as problem and project-based learning (PBL and $\mathrm{PjBL}$ ) as well as group investigation (GI). Several possible models were combined with the online learning; however, this study only considered the assessments of TBLT. Moreover, the application used to support the learning was Schoology, which was well known at the university. The program was quite easy to apply due to having good menus, systems, and subapplication. It also proposed several menus that were simple to operate.

The TBLT model was found to be suitable for online learning just like other methods such as PBL, PjBL, and GI. It was selected for several reasons: (i) TBLT was a potential conventional learning approach; (ii) experts were inspired to implement it in an online learning model; and (iii) before PBL, PjBL, and GI, experts attempted to begin combination with TBLT. The combination of online and offline learning began with the review of materials and conventional TBLT approaches, which advocated learners' improvement of spoken and written language uses. It also relied on learners' fluency before accuracy. Therefore, the communicative language teaching approach is often facilitated for its 
implementation (Richards \& Rodger, 2012). In addition, the online model through blended learning was used to acquire learners' language, although it led to writing skill. Almost all units were completed with a task, which enhanced learners' speaking skills before their writing skills. Writing skills were often produced in the main task of the learning activity due to its output being writing production. Based on this condition, the combination of both models successfully led to learners' language and content mastery for the improvement of writing skills.

\section{Challenges the Students Encountered}

The implementation of blended learning contributed to several challenges for learners and instructors. Besides being slightly experienced, these different challenges were individually felt by the learners. Since learning was divided between direct and online activities, students felt that sharing time between the performance of tasks, exercises, and assignments on campus was highly demanding. Internet connection was the main problem on campus since several students had to share it. This is in line with Qidah (2018), who showed the perception of learners to blended learning model application in EFL grammar classes in Palestine. Additionally, distance learning without meetings with colleagues and lecturers led to socialization problems because students needed social interaction and collaboration when sharing task ideas. These interactions also help to increase social intelligence. Therefore, sociolinguistic competence is difficult to teach via distance learning compared to direct activities (Tawil, 2018). This led to lecturers' inability to observe learners' personality or character, including motivation, anxiety level, courage, and curiosity, which are essential aspects of a successful and meaningful learning process. Interactions also provided learners with more benefits, with students most easily understanding the lesson when they physically encountered the lecturers' performances. For instance, most learners who are introverts, closed off, or shy experienced more convenience when directly interacting with their lecturers via asking questions or having personal consultations (Kaur, 2013). Lecturers further showed that students felt frustrated and considered blended learning time consuming because they were not ready for technologybased education. In addition, students cheated in other online classes because it was difficult for lecturers to control them while learning compared to direct education. This is in line with Mudra's (2018) research regarding EFL classes in Indonesia.

Other students also commented on this form of learning after a semester. For certain reasons, they found that the learning environment was not conducive during blended learning, such as internet connectivity; less technical skill; and learners' indiscipline, frustration, and nonownership of personal computers. Less availability of internet connection on campus was the most frequently mentioned problem, which led to the ownership of their tools. The absence of internet and nonownership of computers also played important roles in the embodiment of success, which was in line with $\mathrm{Al}$ Zumor et al. (2013). Besides internet availability, blended learning success depended greatly on punctuation because the time limit on a certain assignment or test caused significant stress (Hande, S., 2014). To cope with these problems, reliable tools asserting a smooth learning process were very important. These challenges affected learners' performance, causing low academic achievement. Therefore, blended learning was considered a failure in fostering positive effects for students' education. This is in line with Tosun (2015), who showed that blended learning did not improve students' achievement, especially their vocabulary knowledge.

\section{Benefits Students Experienced}

In addition to disadvantages, blended learning had positive impacts because students' perception was also gathered on the model implementation. Based on the focused group discussion with participants, several advantages were obtained from some aspects, namely materials, language skills, flexibility, character, practicality, and improvement.

This learning model further promoted various materials, with students accessing modules uploaded by lecturers and several other resources, such as videos, audio recordings, books, and other links. Materials were modified and presented in better performance because lecturers were able to sort variety from the internet. This is in line with the lecturer method that uses pictures to teach grammar (Qidah, 2008). Furthermore, the selected learning materials provided abundant extensive reading texts, which allowed students to study authentically. This is in line with Ghazizadeh and Fatemiour's (2017) study. An example of this condition was the use of video and audio performed by native English speakers (Mudra, 2018).

Students' language skills also improved. Although the materials were focused on achieving writing skills, they still triggered other language features such as speaking, reading, and listening as well as grammar and analytical skills. Students found the lesson interesting since speaking activities were often involved in the learning activities, which originated once or more in each unit. In addition, this attribute was placed as an initiating activity in the middle or before the main task. Furthermore, speaking was observed to be an effective stimulus for learners through language or expressions, idea explanations, or writers' plan before writing. Students also had the knowledge of what to write, what format to use, and what vocabulary to choose. These inputs were further processed before being made an output (Schmidt, 1990; Widanta, 2017). Although blended learning was not specifically designed for writing, it still had the ability to improve certain skills, such as speaking, listening, spelling, and grammar (Andas \& Bakir, 2013).

Blended learning prioritized flexibility since most students noted the model's fluidity and lack of time limitations (Kaur, 2012; Rahim, 2019; Zumor et al., 2013). This was experienced as long as the proposed materials were not time bound. Furthermore, most of the lesson materials attached on the site were rewound due to being constantly uploaded 
and could also be downloaded any time. Flexibility was also embodied by the situation where the learning was conducted inside and outside the classroom (Ju \& Mei, 2018).

Furthermore, blended learning was able to construct better learner character, with most learners being motivated, enthusiastic, constructive, and inspiring as well as independent. The actual goal of education is for students to be highly motivated, enthusiastic, inspired, and independent (Kaur, 2012; Rahim, 2019; Hande, S., 2014; Oweis, 2018; Akbarov \& Aydogan, 2018). In addition, the achievements of these characters were the highlight of educational goals.

Several perceptions further showed that the designed learning model was practical for reasons such as (i) being massively used at the same time; (ii) being used inside and outside classrooms; and (iii) its learning materials, such as audio, video, presentation, and assessment immediately being updated and repeated. Since resources are easily accessed on the internet, updating learning materials was flexibly conducted any time. This is almost in line with research conducted by S. Hande (2014), Al Zumor (2013), Pappas (2018), and Ju and Mei (2018). Continuous improvement was conclusively found to result from models, approaches, and methods being used to support blended learning. The use of TBLT in this model was also successful. Other models included in blended learning were PjBL, GI, problem solving, advanced organizer, et cetera. Another model successfully inserted was PBL (Tawil, 2018).

\section{CONCLUSION AND SugGestions}

The development of task-based blended learning for an EFL writing class in Polytechnic Negeri Bali was successfully conducted, leading to several conclusions such as the proposed model, the combination of both educational methods, and the challenges and benefit encountered. The development successfully provided a model with learning materials, syntax, and assessment tools. Several simplifications were also made since the conventional materials included some units with similar language functions, purposes, and grammar points. The simplification caused unit minimization and learning hour maximization for students. Furthermore, learning syntax stated that instructors and students had similar perceptions of the learning performances. The assessment tool was formed as a role-play model requiring students to produce a written text such as a business letter that was evaluated with an assessment rubric measuring format, content, grammar, language appropriateness, and concision. This tool contained a Likert scale including four descriptors: need improvement (1), satisfactory (2), very good (3), and excellent (4). Several challenges were further encountered through this developed model, such as anxiety levels, sharing time for task performances and opening site, shortage of socialization, and inadequate communication with teachers (especially for introverts). However, the blended model motivated students for certain reasons, such as the abundant access to materials provided on the site. In addition, elicitation fostered students' self-confidence due to highly coping with the materials. The task of speaking also helped students to accurately comprehend the learning activities.

\section{REFERENCES}

[1] Adas, D., \& Bakir, A. (2013). Writing difficulties and new solutions: Blended learning as an approach to improve writing abilities. International Journal of Humanities and Social Science, 3(9), 254-266.

[2] Akbarov, A., Gonen, K., Aydogan, H. (2018) Students' attitude toward blended learning in EFL context. Acta Diactica Napocensia 11(1), 61-68. Doi:10.24193/and.11.1.5.

[3] Arnawa, et al. (2021). Metaphor about Balinese Women: From semantic analysis to cultural pragmatic interpretations. Language Related Research. Vol.12, no. 5, pp. 1-39. https://lrr.modares.ac.ir. https://doi.org/10.29252/LLR.12.5.

[4] Breem, M. (1987). Laerner Contribution to Task Design. In. C. Candlin and D. Murphy (eds.) Language Learning Task (pp. 23-46) Englewood Cliff 5, N.J.: Prantice Hall.

[5] Burrows, C. (2008). Socio-cultural barriers facing TBL in Japan. The Language Teacher Kancil Teacher, 32/8, 15-19.

[6] Bruton, A. (2002). From tasking purposes to purposing tasks. ELT Journal, 56/3, 280-288.

[7] Dick, W. \& Carey, L. (1990). The Systematic Design of Instruction. Second Edition. Illinois: Scott, Foresman and Company.

[8] Ellis, R. (2003). Task-based language learning and teaching. Oxford: Oxford University Press.

[9] Estaire, S. \& Zanon, J. (1994). Planning class work: A task-based approach. Oxford: Heinemann.

[10] Ghazizadeh, T., \& Fatemipour, H. (2017). The effect of blended learning on EFL learners' reading proficiency. Journal of Language Teaching and Research, 8(3), 606-614.Doi: 10.17507/j1tr.0803.21.

[11] Ginaya, G., et al. (2021). Implementation of e-learning for ESP in Turism during covid-19 pandemic. Journal of Language Teaching and Research, vol. 12, no. 4 pp. 572-578. DOI: http://dx.doi.org/10.17507/jltr.1204.07

[12] Hande, S. (2014). Strength weakness opportunity and threat of blended learning: student's Perception. Annals of Medical and Health Sciences Research. May-June 2014 vol. 4, issue 3, pp.336-339. Retrieved November 11, 2021 from http://www.amhsr.org/.

[13] Hu, G. W. (2005) Contextual influences on instructional practices: a Chinese case for an ecological approach to ELT. TESOL Quarterly, 39, $635-660$.

[14] Ju, S.Y. and Mei S. Y. (2018). Perception and practice of blended learning in foreign language teaching in USIM. European Journal of Social Science Education and Research, Vol. 12, no.1.pp.170-176.

[15] Kaur, M. (2013). Blended learning-its challenges and futures. 3rd World Conference on Learning, Teaching, and Education Leadership (WCLTA. 2012) Procedia-Social and Behavioral Sciences 93 (2013) 612-617

[16] Kirkyoz, Y. (2011). A blended learning study on implementation of video recorded Speaking task in task-based classroom instruction. The Turkish Online Journal of Educational Technology, October 2011 vol.10 issue 4. Pp. 1-13. Retrieved November 5, 2021 
[17] Little, A. \& Fieldsend, T. (2009). Form-focused tasks using semantically enhanced input. The Language Teacher, 33/3, 9-14.

[18] Long, M. H. (1985). A role for instruction in second language acquisition: Task-based language teaching. In K. Hyltenstam, \& M. Pienemann (Eds.), Modeling and accessing second language acquisition (pp. 77-99). Clevedon: Multilingual Matters.

[19] Mackey, A. (1999) Input, interaction and second language development: an empirical study of question formation in ESL. Studies in Second Language Acquisition, 21/4, 557-589.

[20] Mudra, H. (2018). Blended English language learning as a course in an Indonesian context: an exploration toward EFL learner's perceptions. Journal of Foreign Language Education and Technology, 3(2), 2018. http://jflet.com/jflet/. Retrieved October 10, 2021.

[21] Nunan, D. (2005). Important tasks of English education: Asia-wide and beyond. Asian EFL Journal, 7(3). pp. 5-8 from http://www.asian-efl-journal.com/. Retrieved October 10, 2021.

[22] Oweis, T.I. (2018). Effect of using a blended learning method on students' achievement and motivation to learn English in Jordan: A pilot case study. Education Research International volume 2018, article ID 7425924, 7 pages from https://doi.org/10.1155/2018/7425924. Retrieved October 21, 2021.

[23] Pappas, C. (2018). The History of Blended Learning. Retrieved from https://elearningindustry.com./history-of-blended-learning. Retrieved November 11, 2021.

[24] Prabhu, N. S. (1987). Second language pedagogy. Oxford: Oxford university press. On Foreign Languages Journal of Faculty of Letters and Humanities, 41, 45-61.

[25] Qindah, S. (2018). The effects of blended learning on EFL students' usage of grammar in context. The Eurasia Proceedings of Educational and Sciences (EPESS) 2018 vol.10, pp. 11-22.

[26] Rahim, M. N. (2019). The use of blended learning approach in EFL education. International Journal of Engineering and Advanced Technology (IJEAT) Vol.8 Issue 5C. pp. 1165-1168.

[27] Rahimpour, M. (2008). Implementation of task- based approaches to language teaching. Pazhuhesh-e Zabanha-ye Khareji, no. 41, special issue, English, 2008, pp.45-61. From https://wwwreseachgate.net/publication/228637742. Retrieved September 9, 2021.

[28] Richards, J. \& Rodgers, T. (2001). Approaches and methods in language teaching. Cambridge: Cambridge University Press.

[29] Samuda, V. \& Bygate, M. (2008). Tasks in Second Language Learning. Houndmills: Palgrave Macmillan. Asian classrooms. Language Teaching, 40, 243-249.

[30] Sato, R. (2009). Suggestions for creating approaches suitable to the Japanese EFL environment. The Language Teacher, 33/9, $11-14$.

[31] Schmidt, R. (1990). "The role of consciousness in second language learning". Applied Linguistics. 11. 129-158.

[32] Seyyedi, Kaivan. (2012). Task-based Instruction. International Journal of Linguistic V.4 N0 3. Pp.242-251.

[33] Sheen, R. (1994). A critical analysis of the advocacy of the task-based syllabus. TESOL Quarterly, 28/1, $127-151$.

[34] Sheedhouse, P. (2005). 'Task' as a research construct. Language Learning 55, 3, (pp. 533-570).

[35] Skehan, P. (1996). Second Language Acquisition research and task-based instruction. In: Willis, J. \& Willis, D. (1996) (Ed.). Challenge and change in language teaching. Oxford: Heinemann.

[36] Sitawati, et al. (2019). Enhancing Students' Engagement in TBLT: The implementation of mind mapping. Proceeding of Advances in Science, Education \& Humanities Research. V. 354 2nd International Conference on Applied Science and Technology 2019 - Social Sciences Track (iCASTSS 2019) https://www.atlantis-press.com/. Retrieved November 11, 2021.

[37] Somawati, et al. (2017). Can TBL Improve students' Communicative Competence? International Journal of Language and Linguistics, vol.4, no.4, December 2017 http://ijllnet.com/.

[38] Somawati, et al. (2019). Integrating sociological aspects in TBLT: The case of Indonesian EFL class. Journal of Advanced Research in Dynamical and Control Systems, Vol. 11, No. 08-Special Issue on Social Sciences, 2019, http://www.jardcs.org/abstract.php? id=3024 Pages: 2701-2707 ISSN 1943-023X. Retrieved October 7, 2021.

[39] Somawati, et al. (2018). Task-Based Language Teaching: how it is implemented effectively? Journal of Physics, conference series. 953.062075. https://iopscience.iop.org/issue/1742-6596/953/1. Retrieved November 5, 2021.

[40] Swan, M. (2005). Legislating by hypothesis the case of task-based instruction. Applied Linguistics 26. (pp. 376-401) Retrieved November 11, 2021. from http://citeseerx.ist.psu.edu/viewdoc/download? Retrieved November 3, 2021.

[41] Swain, M. (2005). Legislation by hypothesis: the case of task-based instruction. Applied Linguistics, 26/3, 376-401.22

[42] Takimoto, M. (2009). The effects of input-based tasks on the development of learners' pragmatic proficiency. Applied Linguistics, 30/1, 1-25.

[43] Tawil, H. (2018). The blended learning approach and its application in language teaching. International Journal of Language and Linguistics Vol. 5, no.4. 2018 DOI. 10.30845/ijll.v.5.n4p6www.ijllnet.com

[44] Tosun, S. (2015). The effects of blended learning on EFL students' vocabulary enhancement. Procedia-Social and Behavioral Sciences, 199(1), 641-647. https://doi.org/10.1016/j.sbspro.

[45] Widanta, et al. (2017). How should pragmatic be taught at vocational school? International Journal of Language and Linguistics. Vol4. 2. www.ijllnet.com. Pp.110-115. Retrieved August 5, 2021.

[46] Widanta, et al. (2018). Interlanguage request modification: a case in vocational college. Journal of Physics: conference series 953012095, doi:10-1088/1742-6596/953/1/012095, pp.1-8, retrieved June 8, 2021.

[47] Widanta, et al. (2020). Explicit inputs and concept mastery: a case in Indonesian language for foreigner (ILF) instruction. Asian ESP Journal, volume 16, 1 December 2020, pp.101-126. Retrieved August 5, 2021.

[48] Widdowson, H. (1993). Innovation in teacher development. Annual Review of Applied Linguistics, 13, (pp. 260-275).

[49] Willis, J. (1996). A Framework for Task-Based Learning. Harlow: Longman.

[50] Zhang, W., \& Zhu, C. (2018). Comparing learning outcomes of blended learning and traditional face-to-face learning of university students in ESL courses. International Journal on E-Learning, 17(2), 251-273.

[51] Zumor, A.W.Q. et al. (2013). EFL students' perception of a blended learning Environment, advantages, limitation and suggestions for improvement. English Language Teaching. Vol.6, no.10, 2013. www.ccsenet.org/elt. Pp.95-110. Retrieved July $10,2021$. 
Anak Agung Raka Sitawati, works as a permanent English lecturer at Bali State Polytechnic and has been teaching both General English and English for Business for about 29 years. Her research interests are ELT and pragmatics.

I Made Ardana Putra is a permanent English lecturer at Administration department, Politeknik Negeri Bali. His research interests are developing English learning model, developing agro tourism and cultural tourism.

Ni Ketut Suciani is a permanent English lecturer at Administration department, Politeknik Negeri Bali. Her research interests are developing English leaning model and second language acquisition, and English for specific purposes.

I Made Rai Jaya Widanta is an associate professor in Linguistics and is currently working as a permanent lecturer at Politeknik Negeri Bali. His research interests include developing learning model, first and second language acquisition, and inter-language pragmatics.

I Wayan Dana Ardika started his career as an English lecturer in Bali State Polytechnic in 2009. His research interests are both in English education and English literature, including designing learning model, designing engineering dictionary, and pragmatics.

Putu Dyah Hudiananingsih is an associate professor in linguistics. She is assigned to teach English for specific purposes (ESP) particularly that of Accounting English. Her research interest is ESP teaching and teaching writing. 